\title{
HAZARD ANALYSIS AND CRITICAL CONTROL POINTS OF TRADITIONAL VS INDUSTRIAL CREMESCHNITTE PRODUCTION
}

\author{
S. FILIP and R. FINK ${ }^{\mathrm{b} *}$ \\ ${ }^{a}$ Biotechnical Faculty, University of Ljubljana, Jamnikarjeva 101, 1000 Ljubljana. Slovenia \\ ${ }^{\mathrm{b}}$ Faculty of Health Sciences, University of Ljubljana, Zdravstvena pot 5, 1000 Ljubljana. Slovenia
}

(Received: 17 March 2016; accepted: 29 June 2016)

\begin{abstract}
Changes in the consumption habits of the population forces food industry to produce traditional products in modern ways, sometimes not taking into account the modified safety issues. The aim of this study has been to compare hazards and critical control points for traditional and industrial cremeschnitte production. The result shows that the traditional cremeschnitte production includes two additional critical control points, cooking and moulding of egg cream basis, which is essential for safety. In addition, the results of microbial analysis pointed out that the traditional cremeschnitte is safer than the industrial one produced from dried cream powder when comparing Escherichia coli, total aerobic count, and mould contamination $(\mathrm{P}<0.05)$. Moreover, our controlled contamination test with $E$. coli of raw material shows that the traditional cremeschnitte production process reduces microbiological hazard even in the worst-case scenario. All this indicates that traditional food safety practices are not granted and should not be neglected in new production technologies.
\end{abstract}

Keywords: cremeschnitte production, microbial safety, critical control points, thermal treatment

In recent years, more and more consumers are concerned about food safety, especially when taking into account the globalisation of food market. The availability of safe, quality, and locally produced food is important for our health, environment, and economy (Sмітн et al. 2004; Greenhill et al., 2010). In the past, food safety practices were developed based on experience and practical findings while manufacturing the food products. Traditional food was used locally for an extensive period of time, and ingredients or recipes were passed from one generation to another (PANAGOU et al., 2013; TAJKARIMI et al., 2013). The modernized and rapid development of the world has changed food consumption habits that might require food producers' adaptation to new trends (QADRI \& KAYALI, 1998). Especially, demand for precooked, processed, and convenient food can result in food safety failures (TAJKARIMI et al., 2013).

Several researches have studied food safety issues of traditional foods. For instance, JI and co-workers (2007) studied food safety of MiGao, a traditional Chinese steamed cake, and found that total plate counts in the products on the third day of storage were under $10^{3}$ CFU g $\mathrm{g}^{-1}$ and that shelf-life of the product was estimated to be only two or three days. In another study, SAMSON and co-workers (1987) analysed microbiological quality of Tempeh, a traditional Indonesian soybean food, and found that $98 \%$ of the samples exceeded $10^{5}$ $\mathrm{CFU} \mathrm{g}^{-1}$ for Enterobacteriaceae, but also found presence of Staphylococcus aureus, Bacillus cereus, and E. coli. KIM and co-workers (2013) studied microbial quality of food, including cakes, and found that the highest bacterial counts were associated with dried cakes, suggesting

\footnotetext{
* To whom correspondence should be addressed.

Phone: +38613001181; fax: +38613001119; e-mail: rok.fink@zf.uni-lj.si
} 
that appropriate regulations of these food types should be considered. Similarly, UHITIL and co-workers (2004), who analysed microbiological safety of cakes in Croatia, found that $6.4 \%$ of cakes were contaminated with Listeria spp. A report on food poisoning in 2005 in Austria revealed that possible sources of food related illnesses could also be cakes, especially in case of family celebrations (MucH et al., 2007). Epidemiological investigation of food poisoning of 26 persons in United States has revealed Salmonella in cake batter mix, indicating that the industrial premix was contaminated with Salmonella (ZHANG et al., 2007).

A cremeschnitte is a vanilla and custard cream cake popular in several Central European countries. There are many regional variations, but they all include puff pastry base and custard cream. Traditionally, vanilla cream is made of egg yolk, flour, and sugar and it is cooked to given appropriate density. The aim of this study was to provide hazard analysis and identification of critical control points for industrial and traditional cremeschnitte. The second step has been to compare microbiological food safety and to provide controlled test of contamination with E. coli.

\section{Materials and methods}

\subsection{Hazard analysis and identification of critical control points}

Hazard analysis has been provided based on observation of the cremeschnitte process and data collected from a manufacturer. All production steps have been taken in consideration according to the internal HACCP decision tree. The critical control points (CCPs) and control points (CPs) have been determined. The number of CCPs in a process depends on the complexity of the process. The traditional preparation of cremeschnitte includes heat treatment opposite to the industrial technology.

\subsection{Microbial analysis of cremeschnitte}

Microbial analysis of industrial $(\mathrm{n}=50)$ and traditional $(\mathrm{n}=50)$ cremeschnitte was carried out immediately after the production. The samples were homogenized in sterile bags using Stomacher laboratory system. The samples were diluted with sterile water and their microbial contaminations were tested by the following standard methods. Detection of the presence of Salmonella was carried out according to the ISO (2002) standard. The presence of E. coli was tested according to ISO (2005). Enterobacteriaceae were tested according to ISO (2004) standard. S. aureus was analysed according to ISO (1999) standard, total aerobic counts (TAC) according to ISO (2013) standard, mould and yeasts were analysed according to ISO (2008) standard. The results of microbiological analysis for each type of cremeschnitte are presented as average for microorganism tested. The average $\log \mathrm{CFU} \mathrm{g^{-1 }}$ for single microorganism in traditional and industrial cremeschnitte samples were compared by paired Student's $t$-test. The results were compared at the $5 \%$ probability level.

\subsection{Controlled contamination test with E. coli}

In the controlled contamination test $E$. coli were added to raw materials. For industrial cremeschnitte, the cream was prepared from dried cream powder and contaminated with $E$. coli in concentration of $10^{3} \mathrm{CFU}$ per gram of the cream. For traditional cremeschnitte, the eggs that were used for the cream preparation were contaminated with the same concentration of E. coli simulating worst-case scenario of poor hygiene. Both creams were treated as 
proposed in production process simulating the worst-case scenario. For each type of cremeschnitte three parallels and three replications were done. The evaluation method of $E$. coli was the same as described in 1.2 .

\section{Results and discussion}

The transition from traditional to specialised and large scale industrial food producing has brought up the needs for new hazard analysis.

\subsection{Hazard analysis and identification of critical control points}

The results of the hazard analysis show that the production of traditional cremeschnitte is more delicate and sensitive for production errors, which can cause deterioration of the final product and also presents a hazard for consumer. The production steps and related CPs and CCPs are shown in Table 1. The CPs and CCPs are marked with plus symbol (+). Production steps, which are not defined as $\mathrm{CP}$ or $\mathrm{CCP}$, are not marked with plus symbol $(+)$. As shown in Table 1, there are two CCPs (baking of puff pastry and metal detector) that are presented in both types of cremeschnitte production, while traditional cremeschnitte preparation includes another two CCPs, cooking and moulding of egg cream basis, which are essential for safety as well as sensory characteristic and stability of end product. The corrective actions are described in Table 2.

Table 2 shows corrective actions as described in relation to the production process. For industrial cremeschnitte, measures are related to prolonging the baking time and metal detection. Meanwhile, in the traditional cremeschnitte technology, plus action related to the cream cooking procedure and temperature management are expected, too.

\subsection{Microbial analysis of cremeschnitte}

The results of traditional and industrial cremeschnitte analysis show no presence of Salmonella spp. and S. aureus in the samples. In addition, no E. coli was found in the traditional cremeschnitte. For all tested bacteria, more $\log \mathrm{CFU} \mathrm{g}{ }^{-1}$ was found in case of the industrial cremeschnitte in comparison to the traditional one (Fig. 1). The highest levels of bacteria for both cremeschnitte cases were found for TAC, meanwhile, the lowest for mould. These findings indicate that the traditional cremeschnitte is less contaminated with the selected bacteria in comparison to the industrial ones.

Producing the cremeschnitte by traditional recipe is microbiologically safer than using dried cream powder, although in traditional technology fresh eggs are used. One of the reasons could be the cooking of egg cream at $130^{\circ} \mathrm{C}$ for $15 \mathrm{~min}$, where the potential bacterial contamination is managed, in comparison to the industrial cream powder that is only mixed with water without thermal treatment. International Commission on Microbial Specifications has proposed that such food should undergo heating for $2 \mathrm{~min}$ at $70{ }^{\circ} \mathrm{C}$ or high pressure treatment at $500 \mathrm{MPa}$ for $7.5 \mathrm{~min}$ (STEWART et al., 2003). Due to heat treatment of traditional cremeschnitte, lower presence of E. coli, Enterobacteriaceae, and mould was found in comparison to the industrial one. Microbiological quality of raw materials is irrespective of the technological procedure, the most important parameter that can affect the safety of the final product. The microbiological criteria concerning the dried powders like vanilla or vanilla-egg creams are not as strict as they are for fresh eggs. The average criteria for dried 


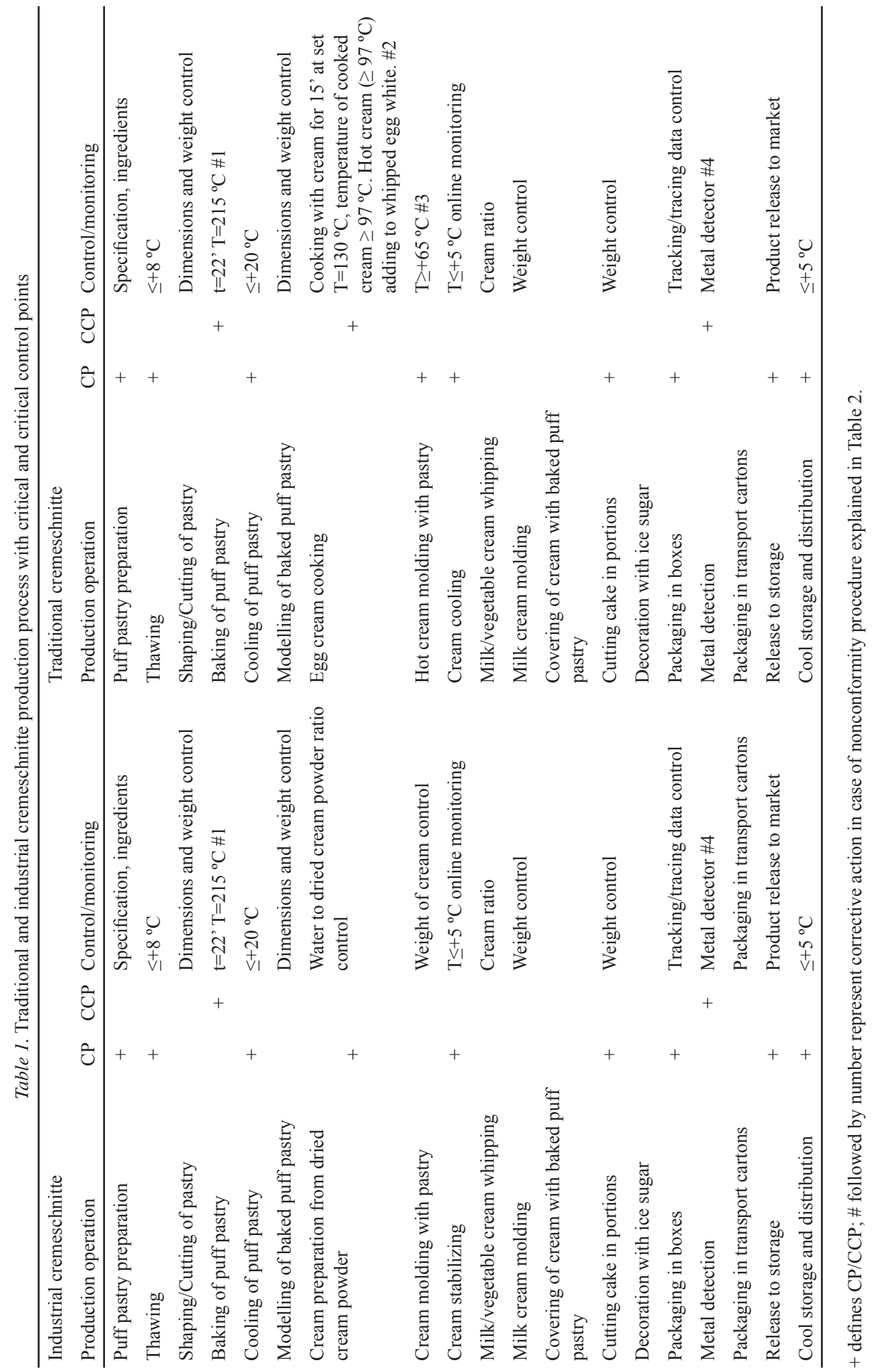




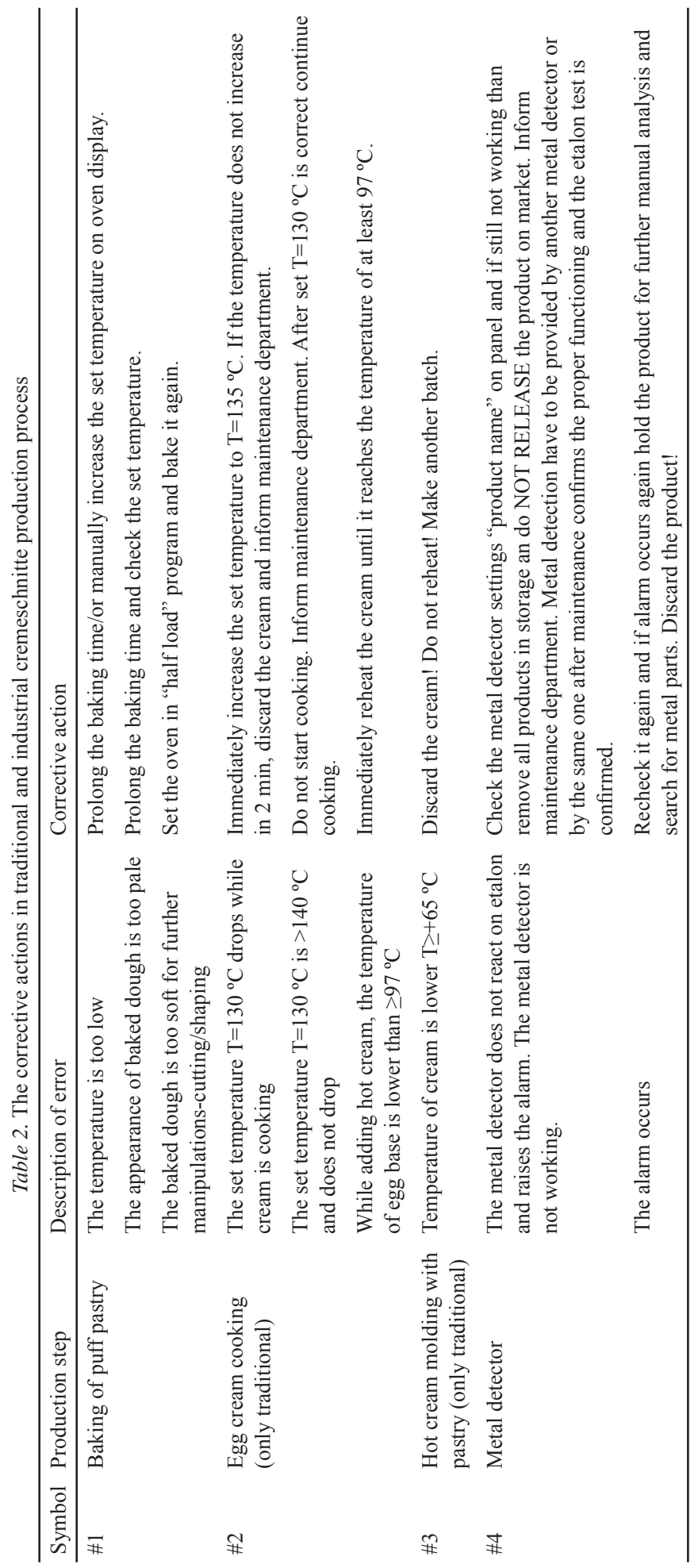


vanilla-egg cream ranged for total aerobic count from $5 \times 10^{3}$ to $1 \times 10^{6} \mathrm{CFU} \mathrm{g}^{-1}$, for moulds from 25 to $1 \times 10^{4} \mathrm{CFU} \mathrm{g}^{-1}$, yeast from 25 to $1 \times 10^{3} \mathrm{CFU} \mathrm{g}^{-1}$, total coliform bacteria and $E$. coli absent in $1 \mathrm{~g}$, and Salmonella spp. absent in $25 \mathrm{~g}$. Meanwhile, criteria for fresh eggs: total aerobic count max $1 \times 10^{4} \mathrm{CFU} \mathrm{g}^{-1}$, total yeast and mould together max $1 \times 10^{2} \mathrm{CFU} \mathrm{g}^{-1}$, and for total coliform bacteria and E. coli absent in $1 \mathrm{~g}$, and Salmonella spp. absent in $25 \mathrm{~g}$. The criteria for dried powders are based on its production, which is usually spray drying, and the fact that the dried powder has water activity $\left(\mathrm{a}_{\mathrm{w}}\right)<0.30$, meanwhile for fresh eggs it is $\mathrm{a}_{\mathrm{w}}>0.95$. The water activity of a wide range of water- and sweet-based creams is also relatively high $a_{w}>0.97$, for fat-based creams, such as chocolate, it is $a_{w}>0.90$, or for some cookies, it is below $\mathrm{a}_{\mathrm{w}}<0.30$. These factors have important influence on microbiological growth and therefore food safety.

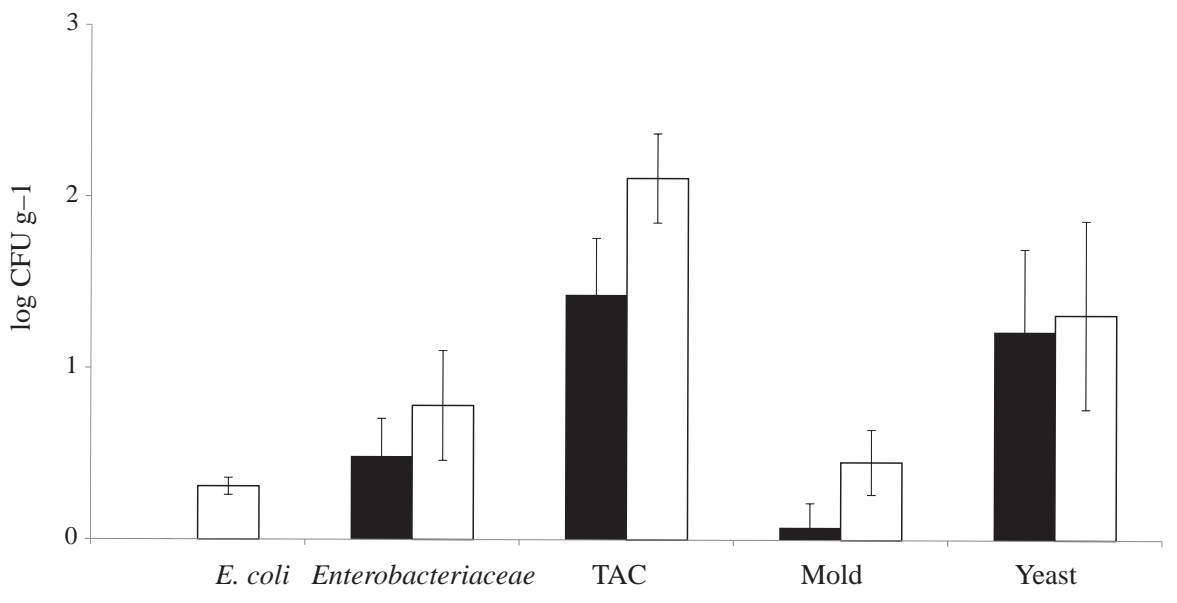

Fig. 1.: Comparison of average $\log \mathrm{CFU} \mathrm{g}^{-1}$ of selected microorganisms in traditional and industrial cremeschnitte ם: Traditional; $\square$ : industrial

Table 3 shows a significantly lower $\log \mathrm{CFU} \mathrm{g}^{-1}$ of $E$. coli for the traditional compared to the industrial cremeschnitte $(\mathrm{P}<0.0001)$. Similar differences can be obtained for TAC and mould, meanwhile no statistical significant difference was found for Enterobacteriaceae and yeast $(\mathrm{P}>0.05)$.

Table 3. Statistical analysis of bacterial presence in the traditional and the industrial cremeschnitte

\begin{tabular}{lcccccc}
\hline Bacteria & $\begin{array}{c}\text { Traditional } \\
\text { average } \\
\operatorname{log~CFU~g~}^{-1}\end{array}$ & $\begin{array}{c}\text { Industrial } \\
\text { average } \\
\operatorname{log~CFU~g}^{-1}\end{array}$ & $\begin{array}{c}\text { Difference } \\
\text { in average }\end{array}$ & $t$-value & $\mathrm{P}$ & Significance \\
\hline E. coli & 0.0000 & 0.3100 & 0.3100 & 4.5647 & 0.0000 & $* *$ \\
Enterobacteriaceae & 0.4861 & 0.7824 & 0.2963 & 1.6000 & 0.1163 & NS \\
TAC & 1.4300 & 2.1102 & 0.6802 & 3.0878 & 0.0044 & $*$ \\
Mould & 0.0741 & 0.4547 & 0.3806 & 2.6936 & 0.0124 & $*$ \\
Yeast & 1.2176 & 1.3129 & 0.0953 & 0.4165 & 0.6792 & NS \\
\hline
\end{tabular}

*: $\mathrm{P}<0.05 ; * *: \mathrm{P}<0.001$; NS: not statistically significant 
Similarly to our study, WinKELHAUSEN and co-workers (2007) analysed traditional homemade cookies for presence of $S$. aureus, sulphite reducing clostridia, and coliform bacteria. The authors reported negative results for all bacteria because of the high baking temperature. In the study of Koтzeкidou (2013), food safety of the industrial produced pastries in Greece were analysed, and the highest Enterobacteriaceae counts were found for desserts with cream, which correspond to our study.

\subsection{Controlled contamination test with E. coli}

The results of our controlled contamination test for traditional and industrial cremeschnitte (averages with standard deviations) show more than $3 \log \mathrm{CFU} \mathrm{g}{ }^{-1}$ reduction of $E$. coli numbers during the production process of the traditional cremeschnitte. Contrary to that for industrial cremeschnitte, a significant increase in $\log \mathrm{CFU} \mathrm{g}^{-1}$ can be observed (Table 4).

Table 4. Results of controlled E. coli contamination test comparing $\log \mathrm{CFU} \mathrm{g}^{-1}$ before and after the production process

\begin{tabular}{lccc}
\hline & $\begin{array}{c}\text { Before production process } \\
\log \text { CFU g }\end{array}$ & $\begin{array}{c}\text { After production process } \\
\log \text { CFU g }\end{array}$ & $\begin{array}{c}\text { Difference } \\
\operatorname{log~CFU~g~}^{-1}\end{array}$ \\
\hline Traditional & $4 \pm 0.2$ & $0.9 \pm 0.01$ & $\downarrow 3.1$ \\
Industrial & $4 \pm 0.3$ & $8 \pm 0.2$ & $\uparrow 4$ \\
\hline
\end{tabular}

$\downarrow$ : decrease; $\uparrow:$ increase

\section{Conclusions}

Our traditional attitude to food is changing along with the safety issues of food production. Modern, industrialized, and mass made food products are not granted safe as our research has shown. Traditional cremeschnitte is from microbiological point of view safer due to the egg cream thermal treatment in comparison to dried cream powder. Moreover, our controlled test of $E$. coli contamination shows that in worst-case scenario the traditional cremeschnitte will be safer that industrial one. All this indicates that traditional experiences in food safety practices are not self-evident and should not be neglected in modern technology.

\section{References}

Greenhill, A.R., Shipton, W.A., Blaney, B.J., Amoa, B., Kopel, E., Pelowa, D., Gena, M. \& Warner, J.M. (2010): Hazards and critical control points for traditional sago starch production in Papua New Guinea: Implications for food safety education. Food Control, 21, 657-662.

ISO (1999): Microbiology of food and animal feeding stuffs - Horizontal method for the enumeration of coagulasepositive staphylococci (Staphylococcus aureus and other species). No. 6888.

ISO (2002): Microbiology of food and animal feeding stuffs - Horizontal method for the detection of Salmonella spp. No. 6579.

ISO (2004): Microbiology of food and animal feeding stuffs - Horizontal methods for the detection and enumeration of Enterobacteriaceae. No. 21528-2.

ISO (2005): Microbiology of food and animal feeding stuffs - Horizontal method for the detection and enumeration of presumptive Escherichia coli - Most probable number technique. No. 7251. 
ISO (2008): Microbiology of food and animal feeding stuffs - Horizontal method for the enumeration of yeasts and moulds. No. 21527-1-2.

ISO (2013): Microbiology of the food chain - Horizontal method for the enumeration of microorganisms - Part 2: Colony count at 30 degrees $C$ by the surface plating technique. No. 4833-2.

Ji, Y., Zhu, K., Qian, H. \& Zhou, H. (2007): Microbiological characteristics of cake prepared from rice flour and sticky rice flour. Food Control, 18, 1507-1511.

KIM, M.J., KIM, S.A., Kang, Y.S., HwAng, I.G. \& RHEE, M.S. (2013): Microbial diversity and prevalence of foodborne pathogens in cheap and junk foods consumed by primary schoolchildren. Lett. Appl. Microbiol., 57(1), 47-53.

KotzeKidou, P. (2013): Microbiological examination of ready-to-eat foods and ready-to-bake frozen pastries from university canteens. Food Microbiol., 34, 337-343.

Much, P., Pichler, J. \& Allerberger, F. (2007): Lebensmittelbedingte infektiöse Krankheitsausbrüche, Österreich 2005. Wien. klin. Wochenschr., 119(5-6), 150-157.

Panagou, E.Z., Nychas, G.J.E. \& Sofos, J.N. (2013): Types of traditional Greek foods and their safety. Food Control, 29(1), 32-41.

QADRI, S.M.H. \& KAYALI, S. (1998): Enterohemorrhagic Escherichia coli: A dangerous food-borne pathogen. Postgraduate Med., 103(2), 179-187.

Samson, R.A,. Van Kooij, J.A. \& De Boer, E. (1987): Microbiological quality of commercial tempeh in the Netherlands. J Food. Protect., 50(2), 92-94.

Smith, J.P., Daifas, D.P., El-Khoury, W., Koukoutsis, J. \& El-Khoury, A. (2004): Shelf life and safety concerns of bakery products - A review. Crit. Rev. Food Sci. Nutr., 44(1), 19-55.

Stewart, C.M., Cole, M.B. \& Schaffner, D.W. (2003): Managing the risk of staphylococcal food poisoning from cream-filled baked goods to meet a food safety objective. J. Food Protect., 66, 1310-1325.

Tajkarimi, M., Ibrahim, S.A. \& Fraser, A.M. (2013): Food safety challenges associated with traditional foods in Arabic speaking countries of the Middle East. Trends Food Sci. Tech., 29(2), 116-123.

Uhitil, S., Jakšić, S., Petrak, T., Medić, H. \& Gumhalter-Karolyi, L. (2004): Prevalence of Listeria monocytogenes and the other Listeria spp. in cakes in Croatia. Food Control, 15(3), 213-216.

Winkelhausen, E., Jovanovic-Malinovska, R., Velickova, E. \& Kuzmanova, S. (2007): Sensory and microbiological quality of a baked product containing xylitol as an alternative sweetener. Int. J. Food Prop., 10, 639-649.

Zhang, G., Ma, L., Patel, N., Swaminathan, B., Wedel, S. \& Doyle, M.P. (2007): Isolation of Salmonella Typhimurium from outbreak-associated cake mix. J. Food Protect., 70, 997-1010. 